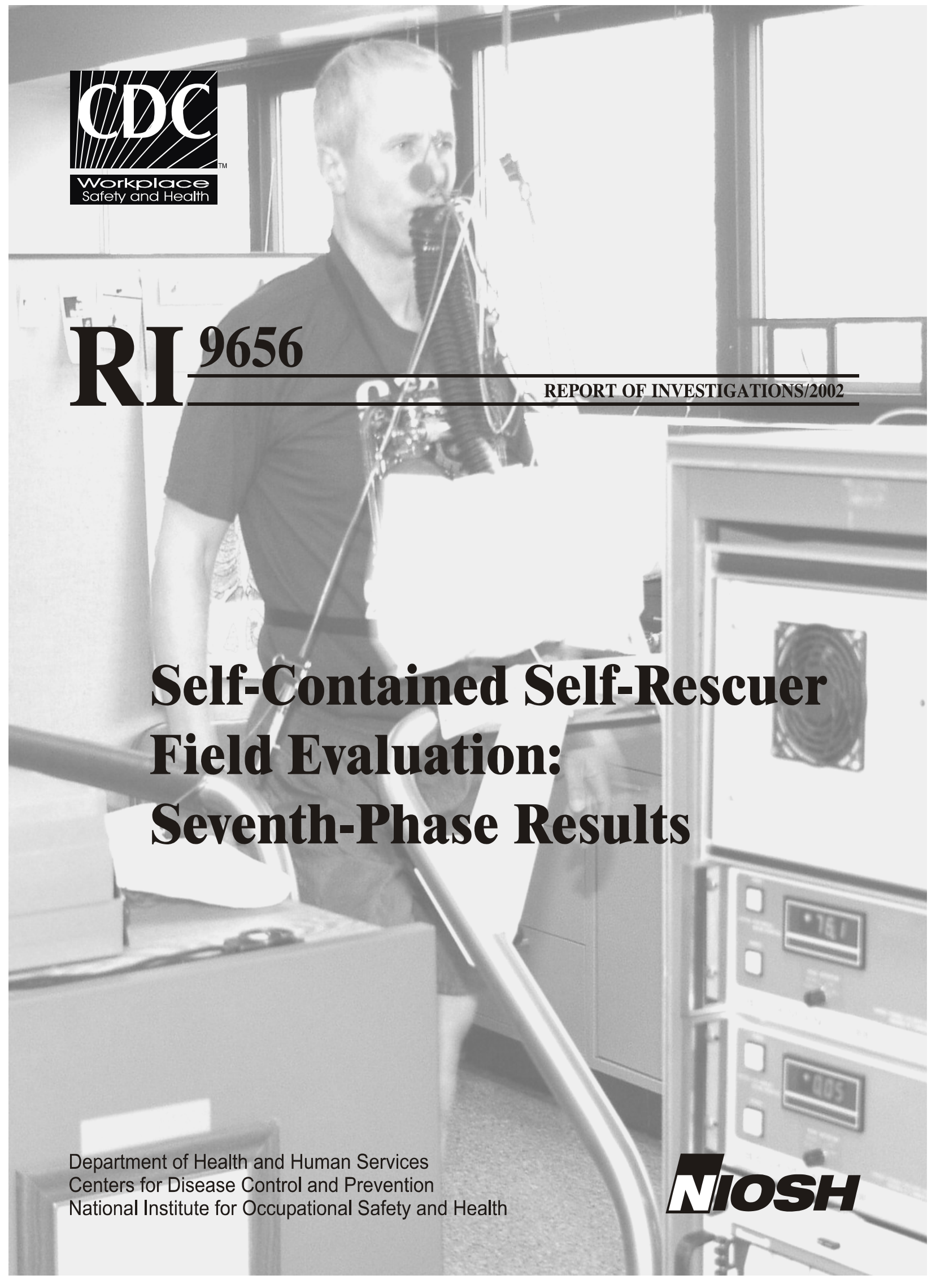


Report of Investigations 9656

\title{
Self-Contained Self-Rescuer Field Evaluation: Seventh-Phase Results
}

\author{
Nicholas Kyriazi and John P. Shubilla
}

U.S. DEPARTMENT OF HEALTH AND HUMAN SERVICES

Centers for Disease Control and Prevention

National Institute for Occupational Safety and Health

National Personal Protective Technology Laboratory

Pittsburgh, PA

March 2002 


\title{
ORDERING INFORMATION
}

\author{
Copies of National Institute for Occupational Safety and Health (NIOSH) \\ documents and information \\ about occupational safety and health are available from \\ NIOSH-Publications Dissemination \\ 4676 Columbia Parkway \\ Cincinnati, OH 45226-1998
}

$\begin{array}{ll}\text { FAX: } & 513-533-8573 \\ \text { Telephone: } & \begin{array}{l}1-800-35-N I O S H \\ (1-800-356-4674)\end{array} \\ \text { E-mail: } & \text { pubstaft@cdc.gov } \\ \text { Web site: } & \text { www.cdc.gov/niosh }\end{array}$

This document is the public domain and may be freely copied or reprinted.

Disclaimer: Mention of any company or product does not constitute endorsement by NIOSH.

DHHS (NIOSH) Publication No. 2002-127 


\section{CONTENTS}

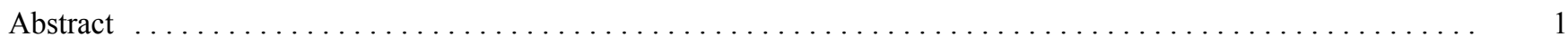

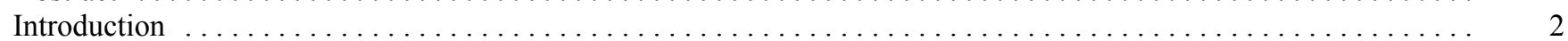

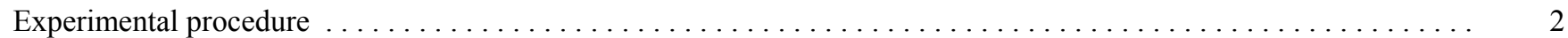

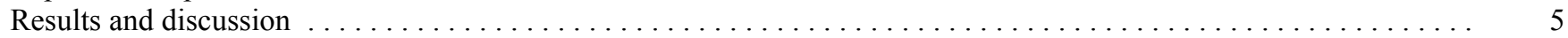

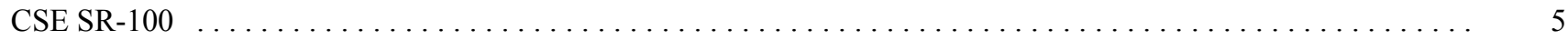

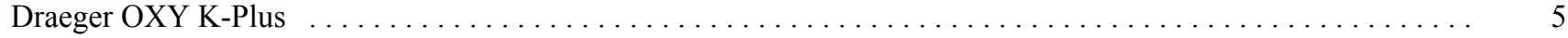

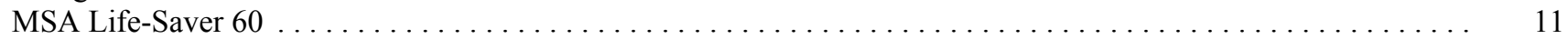

Ocenco EBA $6.5 \ldots \ldots \ldots \ldots \ldots \ldots \ldots \ldots \ldots \ldots \ldots \ldots \ldots \ldots \ldots \ldots \ldots \ldots \ldots \ldots \ldots \ldots \ldots \ldots \ldots \ldots \ldots \ldots$

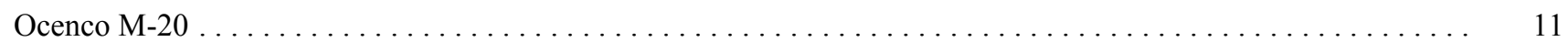

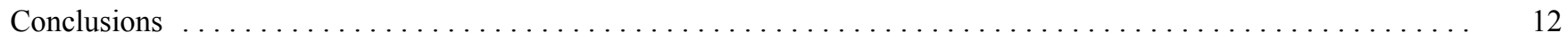

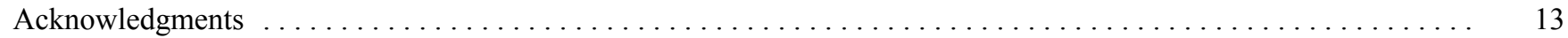

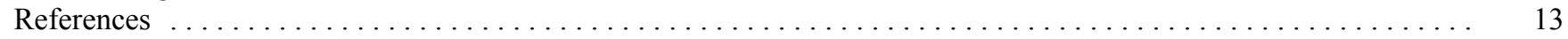

\section{ILLUSTRATIONS}

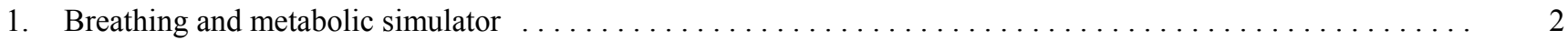

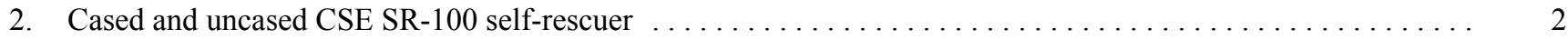

3. Cased and uncased Draeger OXY K-Plus self-rescuer $\ldots \ldots \ldots \ldots \ldots \ldots$

4. Cased and uncased MSA Life-Saver 60 self-rescuer $\ldots \ldots \ldots \ldots \ldots \ldots$

5. Cased and uncased Ocenco EBA 6.5 self-rescuer $\ldots \ldots \ldots \ldots \ldots \ldots \ldots \ldots \ldots$

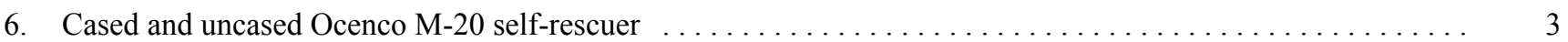

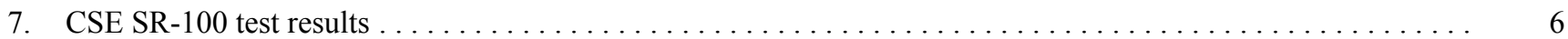

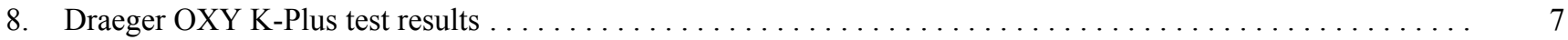

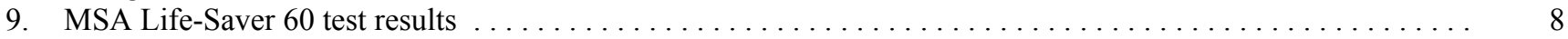

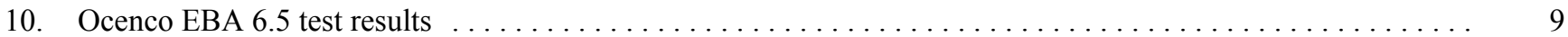

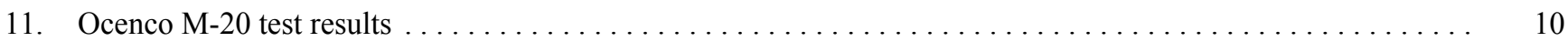

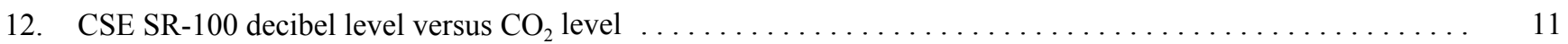

TABLES

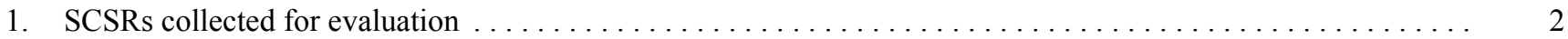

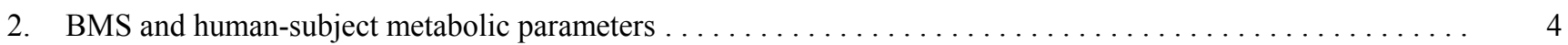

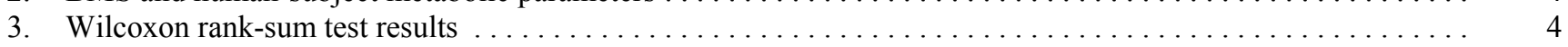

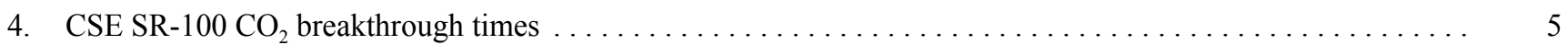

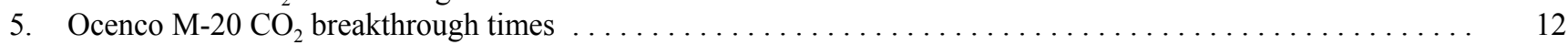




\section{UNIT OF MEASURE ABBREVIATIONS USED IN THIS REPORT}

$\begin{array}{ll}\text { breaths/min } & \text { breaths per minute } \\ \mathrm{hr} & \text { hour(s) } \\ \mathrm{kg} & \text { kilograms(s) } \\ \mathrm{L} & \text { liter(s) } \\ \mathrm{L} / \text { breath } & \text { liter(s) per breath }\end{array}$

$\mathrm{L} /$ min liter(s) per minute

min minute(s)

$\mathrm{mL} / \mathrm{min}$ milliliter(s) per minute

$\mathrm{mm} \mathrm{H}_{2} \mathrm{O}$ millimeter(s) of water (pressure)

ppm parts per million 


\title{
SELF-CONTAINED SELF-RESCUER FIELD EVALUATION: SEVENTH-PHASE RESULTS
}

\author{
By Nicholas Kyriazi ${ }^{1}$ and John P. Shubilla ${ }^{2}$
}

\begin{abstract}
The National Institute for Occupational Safety and Health, National Personal Protective Technology Laboratory, has undertaken a study to determine how well self-contained self-rescuers (SCSRs), deployed in accordance with Federal regulations (30 CFR 75.1714), hold up in the underground environment with regard to both physical damage and aging. This report presents findings regarding laboratory-tested SCSRs in the seventh phase of testing from May 1999 to August 2000. The SCSRs were tested on human subjects and on a breathing and metabolic simulator. The results indicate that most of the apparatus, if they pass their approved inspection criteria, perform satisfactorily. The deployed CSE SR-100s, however, exhibited significantly higher inhaled carbon dioxide $\left(\mathrm{CO}_{2}\right)$ levels than new units, as they did in the previous two phases. Several Draeger OXY K-Pluses that rattled when shaken were found to have potassium superoxide $\left(\mathrm{KO}_{2}\right)$ particles throughout the breathing circuit, including the mouthpiece. Draeger investigated the problem and developed a shake test to detect damaged units. The durations of new Ocenco M-20s were statistically significantly longer than those of deployed units, although only by $2 \mathrm{~min}$.
\end{abstract}

\footnotetext{
${ }^{1}$ Biomedical engineer.

${ }^{2}$ Engineering technician.

National Personal Protective Technology Laboratory, National Institute for Occupational Safety and Health, Pittsburgh, PA.
} 


\section{INTRODUCTION}

On June 21, 1981, U.S. coal mine operators were required to make available to each underground coal miner a self-contained self-rescuer (SCSR). The regulations (30 CFR 75.1714) require that each person in an underground coal mine wear, carry, or have immediate access to a device that provides respiratory protection with an oxygen $\left(\mathrm{O}_{2}\right)$ source for at least $1 \mathrm{hr}$, as approved by the certifying agencies - the National Institute for Occupational Safety and Health (NIOSH) in Morgantown, WV, and the Mine Safety and Health Administration (MSHA). The NIOSH National Personal Protective Technology Laboratory (NPPTL) and MSHA are conducting a long-term evaluation of
SCSRs deployed in underground coal mines. NPPTL locates mines willing to participate in the study and trades deployed SCSRs for new ones in cooperation with MSHA. NPPTL then tests the deployed SCSRs. The objective of this program is to evaluate the in-mine operational durability of deployed SCSRs. Of utmost concern is the successful performance of any SCSR that passes its approved inspection criteria. Such apparatus must function successfully to enable a miner to escape safely during a mine emergency. Apparatus that fail inspection are expected to be removed from service.

\section{EXPERIMENTAL PROCEDURE}

This study involves testing approximately 100 SCSRs in each phase. This report describes findings in the seventh phase of testing from May 1999 to August 2000. Previous reports describe phases 1 through 6 [Kyriazi et al. 1986; Kyriazi and Shubilla 1992, 1994, 1996, 2000]. Ninety percent of the apparatus were tested on a breathing and metabolic simulator (BMS) (figure 1) and $10 \%$ on human subjects on a treadmill.

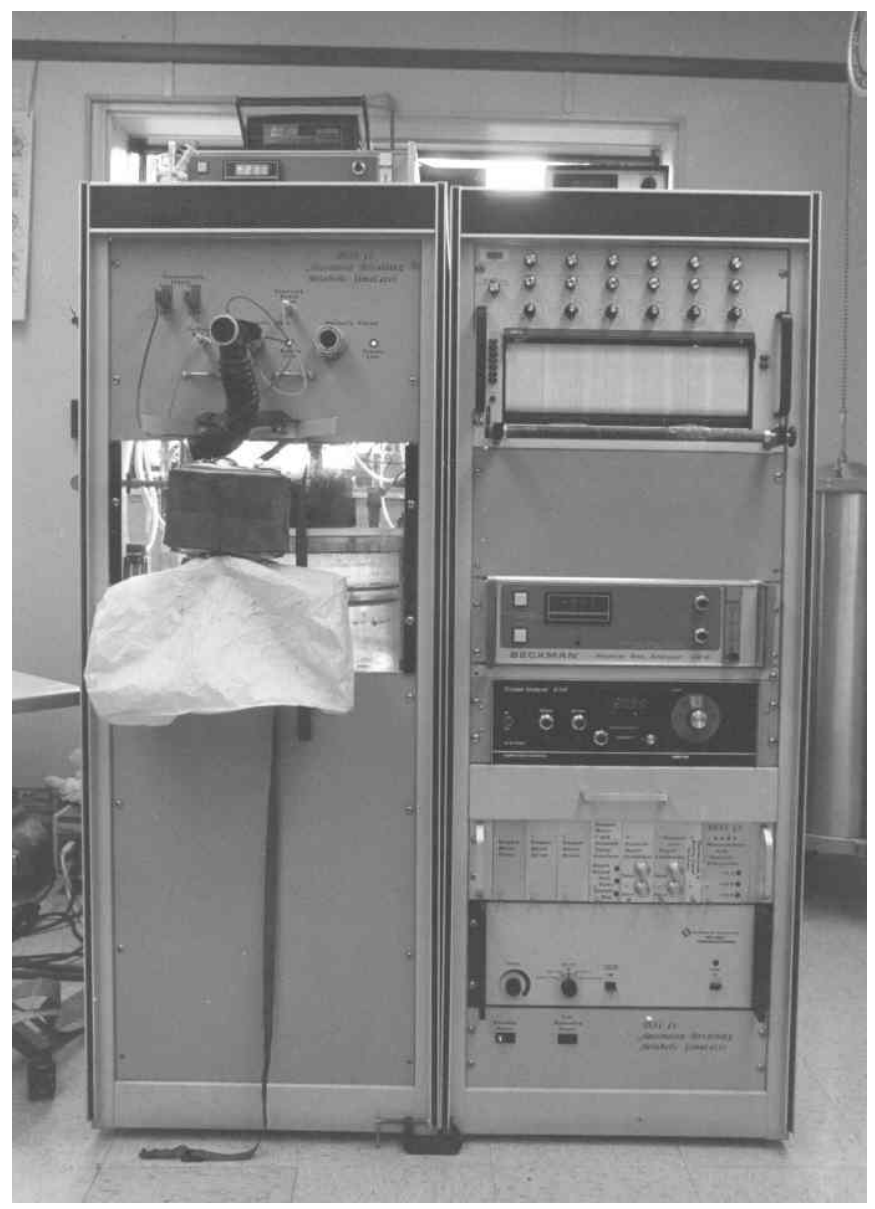

Figure 1.-Breathing and metabolic simulator.
MSHA supplies some of the human test subjects from its Mine Emergency Unit for treadmill testing.

The SCSRs tested were manufactured by CSE Corp., Draegerwerk AG, Mine Safety Appliances Co., Inc. (MSA), and Ocenco, Inc. They were sampled according to estimated market share (table 1). The apparatus are shown in figures 2 through 6.

Table 1.-SCSRs collected for evaluation

\begin{tabular}{|c|c|c|}
\hline Apparatus & $\begin{array}{l}\text { Market } \\
\text { share }\end{array}$ & $\begin{array}{l}\text { No. received } \\
\text { and tested }\end{array}$ \\
\hline CSE SR-100 & 46 & 46 \\
\hline Draeger OXY K-Plus & 5 & 10 \\
\hline MSA Life-Saver 60 . & 7 & 11 \\
\hline Ocenco EBA 6.5 & 39 & 30 \\
\hline Ocenco M-20 & 2 & 10 \\
\hline Total & - & 107 \\
\hline
\end{tabular}

The $\mathrm{O}_{2}$ constant-flow rate is checked on the Ocenco EBA 6.5 , a compressed- $\mathrm{O}_{2}$ apparatus. The NIOSH-required flow is $1.5 \mathrm{~L} / \mathrm{min}$ at ambient temperature and pressure (at $\mathrm{NIOSH}$ in Morgantown, WV), dry (ATPD).

All apparatus in this study are checked for breathing circuit leak tightness after opening. The leak test used is that recommended by Draeger for its BG-174A rescue breathing

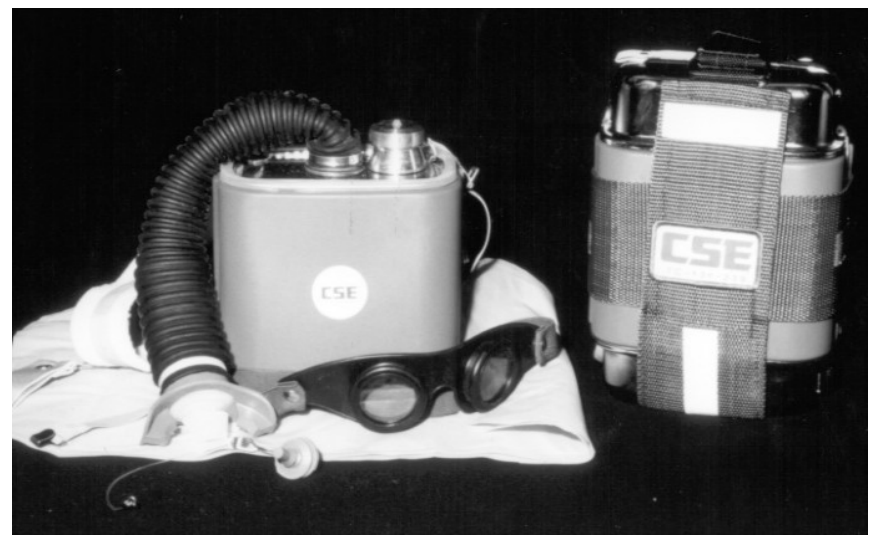

Figure 2.-Cased and uncased CSE SR-100 self-rescuer. 


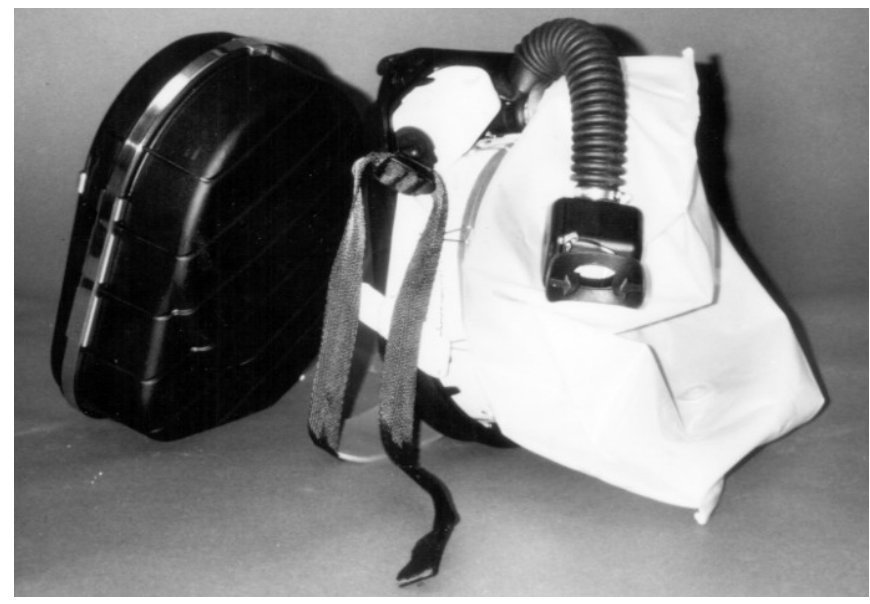

Figure 3.-Cased and uncased Draeger OXY K-Plus selfrescuer.

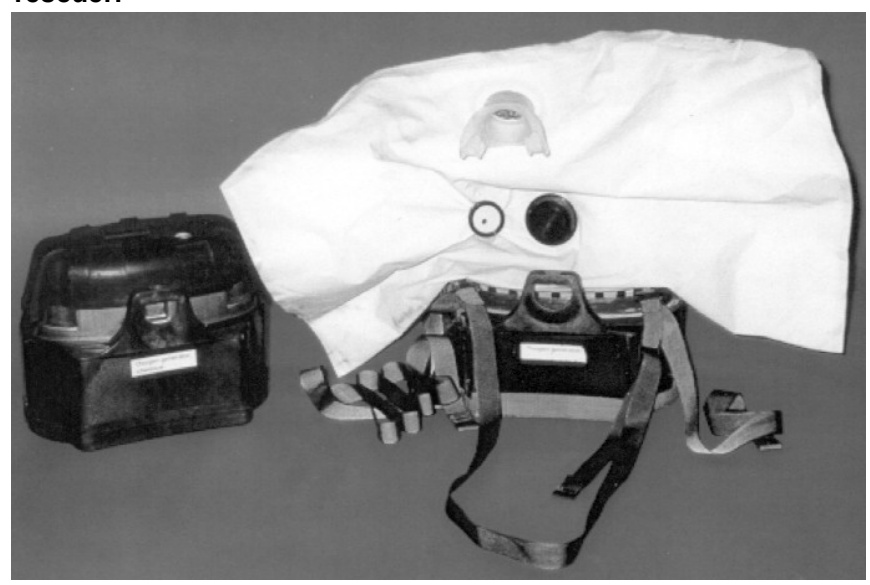

Figure 4.-Cased and uncased MSA Life-Saver 60 self-rescuer.

apparatus. It is performed to determine how well the apparatus isolates the user from the environment, which may be irrespirable in an emergency. Passing this test is not a requirement of the current regulations for these apparatus, however. The test permits a decay in breathing circuit pressure from -70 to $-60 \mathrm{~mm} \mathrm{H}_{2} \mathrm{O}$ in $1 \mathrm{~min}$. We have determined that just passing the test is equivalent to a leak rate of approximately $1 \mathrm{~mL} / \mathrm{min}$ given an internal volume for both the apparatus and test stand of $1 \mathrm{~L}$ (all volumes in this report are given at standard temperature $\left(0^{\circ} \mathrm{C}\right)$ and pressure, dry, unless otherwise noted $)$. To give this some perspective, an in-leakage rate of $87 \mathrm{~mL} / \mathrm{min}$ in a $10 \% \mathrm{CO}$ atmosphere at a peak inhalation flow rate of $250 \mathrm{~L} / \mathrm{min}$ will result in the 8-hr threshold limit value (TLV) for CO of $35 \mathrm{ppm}$. The $250 \mathrm{~L} / \mathrm{min}$ peak inhalation flow rate is used because this occurs at roughly an $80 \mathrm{~L} / \mathrm{min}$ ventilation rate, the highest likely such rate that can reasonably be expected of a user. At such a maximal work rate, inhalation pressure should not exceed $-300 \mathrm{~mm} \mathrm{H}_{2} \mathrm{O}$, the highest negative pressure tolerated by $80 \%$ of test subjects in a recent study [Hodgson 1993]. At the leak test pressure of $-70 \mathrm{~mm} \mathrm{H}_{2} \mathrm{O}$, the proportional in-leakage rate resulting in the 8 -hr TLV would be $20 \mathrm{~mL} / \mathrm{min}$ at a peak

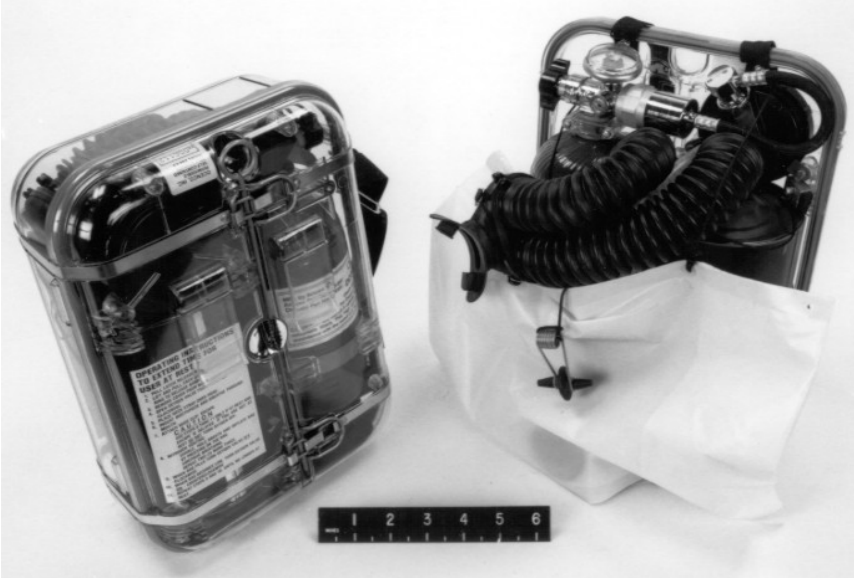

Figure 5.-Cased and uncased Ocenco EBA 6.5 self-rescuer.

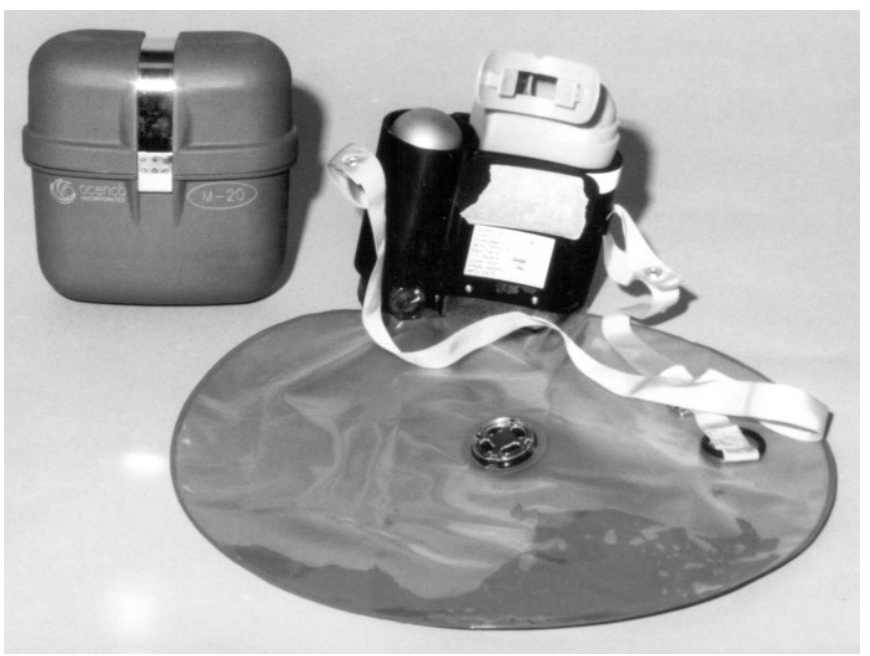

Figure 6.-Cased and uncased Ocenco M-20 self-rescuer.

inhalation flow rate of $58 \mathrm{~L} / \mathrm{min}$. The Draeger leak test, therefore, can be considered very conservative when applied under these circumstances.

NPPTL selected the participating mines with regard to type of mining operation, coalbed height, and SCSR deployment mode in order to obtain a wide range of deployment impact. Deployment modes included permanent storage on the ground, on a mantrip or mining machine, or belt-worn.

The BMS test consisted of the average metabolic work rate exhibited by the 50th-percentile miner weighing $87 \mathrm{~kg}$ while performing the 1-hr man test 4 as described in 42 CFR 84 . However, even though the average work rate is the same, NPPTL testing is not equivalent to the certification testing at NIOSH-Morgantown. The certification testing imposes high and low work rates that the average, used at NPPTL, does not. Also, the stressor levels are continuously monitored at NPPTL, whereas they are sampled only between work activities in the certification testing. In addition, NPPTL testing continues until the apparatus is empty, whereas testing during certification ends at a predetermined time - the rated duration - even though the capacity of the apparatus usually exceeds this, sometimes 
considerably. Therefore, an apparatus that fails NPPTL testing would not necessarily fail certification, and vice versa. In the treadmill testing, the human subjects walked at whatever speed and grade resulted in an $\mathrm{O}_{2}$ consumption rate of $1.35 \mathrm{~L} / \mathrm{min}$. The $\mathrm{CO}_{2}$ production rate, ventilation rate, and respiratory frequency varied in the test subjects. The metabolic parameters for both BMS and human subjects are given in table 2. The BMS $\mathrm{CO}_{2}$ production rate was lowered in this phase of testing to $1.15 \mathrm{~L} / \mathrm{min}$ from $1.30 \mathrm{~L} / \mathrm{min}$ in the last two phases to better match the average rate of the human test subjects currently used in the study.

The parameters monitored were inhaled levels of $\mathrm{CO}_{2}$ and $\mathrm{O}_{2}$, end-of-inhalation wet- and dry-bulb temperatures, and inhalation and exhalation peak breathing pressures in both the BMS and treadmill testing. In the BMS testing, however, average inhaled levels of gas concentration were measured as opposed to the minimum values of $\mathrm{CO}_{2}$ and maximum values of $\mathrm{O}_{2}$ in the treadmill testing. Average inhaled gas levels include the effect of apparatus dead space, whereas minimum values of $\mathrm{CO}_{2}$, for example, are only the lowest level of gas concentration during inhalation. The BMS measures average inhaled values by electronically summing all of the $\mathrm{CO}_{2}$ and $\mathrm{O}_{2}$ over each inhalation cycle, weighted by the instantaneous flow rate. The BMS also measures minimum inhaled $\mathrm{CO}_{2}$ levels.

Tests on the BMS were terminated upon exhaustion of the $\mathrm{O}_{2}$ supply as indicated by negative pressures reaching $-200 \mathrm{~mm} \mathrm{H}_{2} \mathrm{O}$ coinciding with an empty breathing bag. If average inhaled $\mathrm{CO}_{2}$ levels exceed $10 \%$ or $\mathrm{O}_{2}$ levels fall below $15 \%$, the accuracy of the metabolism of the BMS becomes questionable, and tests were terminated at those points or shortly afterward. Treadmill tests were terminated when the $\mathrm{O}_{2}$ supply was exhausted, if minimum inhaled $\mathrm{CO}_{2}$ exceeded $4 \%$, if maximum inhaled $\mathrm{O}_{2}$ fell below $15 \%$, or if the test subject stopped because of subjectively high breathing pressures or temperatures.

The Wilcoxon rank-sum test was performed for each monitored stressor to determine whether or not the deployed units behaved differently from new units. It tests the hypothesis that the two samples are from populations with the same mean. The values from both samples are ranked in ascending order of magnitude. If the sum of the ranks of the smaller sample (T) (in this case, new units) falls within the acceptable range for the given sample sizes, then there is not sufficient evidence at the specified probability level (" =.05, two-sided) to say that the means of the two samples differ. The rank-sum test does not rely upon the assumptions that either the new- or deployed-unit data are normal distributions or that they have identical variances, as does the t-test for two populations of independent samples. One limitation of the Wilcoxon rank-sum test is that it does not distinguish between large and small differences in values. The results of the two-sided, " $=0.05$, Wilcoxon ranksum tests are presented in table 3 . The probability of $\mathrm{T}$ falling outside the given range is 0.05 if the populations have the same mean.

Table 2.-BMS and human-subject metabolic parameters

\begin{tabular}{|c|c|c|c|c|}
\hline Metabolic workload & BMS & Subject A & Subject B & Subject C \\
\hline $\mathrm{O}_{2}$ consumption rate $\ldots \ldots \ldots \ldots$ L/min $\ldots$ & 1.35 & 1.35 & 1.35 & 1.35 \\
\hline $\mathrm{CO}_{2}$ production rate $\ldots \ldots \ldots$ L/min $\ldots$ & 1.15 & 1.12 & 1.18 & 1.00 \\
\hline Ventilation rate $\ldots$. & 30.0 & 27 & 22 & 28 \\
\hline Tidal volume $\ldots \ldots \ldots \ldots \ldots$. . . L/breath . . & 1.68 & 1.59 & 2.20 & 2.00 \\
\hline $\begin{array}{l}\text { Respiratory frequency ...... breaths/min . . } \\
\text { Peak respiratory flow rate: }\end{array}$ & 17.9 & 17 & 10 & 14 \\
\hline Inhalation $\ldots \ldots \ldots$ & 89 & $(1)$ & $\left({ }^{1}\right)$ & $\left({ }^{1}\right)$ \\
\hline Exhalation $\ldots \ldots \ldots \ldots \ldots \ldots$ L/min . . & 71 & $(1)$ & $\left({ }^{1}\right)$ & $\left({ }^{1}\right)$ \\
\hline
\end{tabular}

Table 3.-Wilcoxon rank-sum test results

\begin{tabular}{|c|c|c|c|c|c|c|c|c|c|c|c|c|c|c|}
\hline \multirow[t]{2}{*}{ Apparatus } & \multicolumn{2}{|c|}{ Duration } & \multicolumn{2}{|c|}{$\begin{array}{c}\text { Average } \\
\text { inhaled } \mathrm{CO}_{2}\end{array}$} & \multicolumn{2}{|c|}{$\begin{array}{c}\text { Average } \\
\text { inhaled } \mathrm{O}_{2}\end{array}$} & \multicolumn{2}{|c|}{$\begin{array}{c}\text { Wet-bulb } \\
\text { temperature }\end{array}$} & \multicolumn{2}{|c|}{$\begin{array}{c}\text { Dry-bulb } \\
\text { temperature }\end{array}$} & \multicolumn{2}{|c|}{$\begin{array}{l}\text { Inhalation } \\
\text { pressure }\end{array}$} & \multicolumn{2}{|c|}{$\begin{array}{c}\text { Exhalation } \\
\text { pressure }\end{array}$} \\
\hline & Range & $\bar{T}$ & Range & $\bar{T}$ & Range & $\mathrm{T}$ & Range & $\bar{T}$ & Range & $\bar{T}$ & Range & $\mathrm{T}$ & Range & $\bar{T}$ \\
\hline SR-100 & $15-60$ & 42 & $15-60$ & 4 & $15-60$ & 45 & $15-60$ & 66 & $15-60$ & 63 & $15-60$ & 34 & $15-60$ & 46 \\
\hline OXY K-Plus & $8-31$ & 25 & $8-31$ & 22 & $8-31$ & 29 & $8-31$ & 22 & $8-31$ & 24 & $8-31$ & 22 & $8-31$ & 18 \\
\hline Life-Saver 60 & $9-33$ & 21 & $9-33$ & 16 & $9-33$ & 16 & $9-33$ & 25 & $9-33$ & 28 & $9-33$ & 16 & $9-33$ & 19 \\
\hline EBA 6.5 . & $18-75$ & 32 & $18-75$ & 26 & $18-75$ & 70 & $18-75$ & 46 & $18-75$ & 62 & $18-75$ & 36 & $18-75$ & 20 \\
\hline$M-20 \ldots \ldots \ldots$ & $8-31$ & 33 & $8-31$ & 20 & $8-31$ & 16 & $8-31$ & 27 & $8-31$ & 31 & $8-31$ & 22 & $8-31$ & 8 \\
\hline
\end{tabular}

$\mathrm{T}^{\mathrm{I}}$ Sum of the ranks of the smaller sample (new units). 


\section{RESULTS AND DISCUSSION}

Experience with each model of apparatus is discussed separately. The minute-average values of the monitored stressors were averaged over the entire test duration and are presented graphically (figures 7-11) for each apparatus by stressor. The values for new units tested on the BMS can be compared with those for deployed units tested on the BMS and, to some extent, with those for deployed units tested on human subjects on a treadmill, which are plotted afterward. Because human subjects may differ from each other and from the BMS in terms of $\mathrm{CO}_{2}$ production rate, ventilation rate, and respiratory frequency, all of which affect apparatus duration as well as all of the monitored stressors, treadmill tests cannot be considered equivalent to the BMS tests even though the $\mathrm{O}_{2}$ consumption rate is the same. Missing data points for wet-bulb temperature indicate equipment malfunction or inability to instrument apparatus.

\section{CSE SR-100}

In addition to the 40 apparatus targeted for collection in this phase, we tested an additional 6 units received from the United Mine Workers of America, at their request, for a total of 46 SR-100s.

Of 44 deployed units checked for breathing circuit leaks, 34 passed. Two of the three new apparatus checked for leaks passed.

As in the previous two phases, the Wilcoxon rank-sum test $[\mathrm{M}=3 ; \mathrm{N}=21]$ for average inhaled $\mathrm{CO}_{2}$ showed a significant difference between new and deployed units, with deployed units having higher values than new ones (table 3 ). CSE's noise test, developed to detect bed degradation, was not being used at the mines during the collection of all the apparatus in this phase of testing. Therefore, some apparatus were collected that had noise levels that would have required them to be removed from service. They were tested anyway to see how they performed. In general, the higher the decibel level, the higher the $\mathrm{CO}_{2}$ level; however, the correlation coefficient was only 0.51 in this phase versus 0.85 for 17 apparatus tested in the previous phase. We have no explanation for this disparity at present but, for the apparatus tested here, only when decibel levels were under 34 was one guaranteed that average inhaled $\mathrm{CO}_{2}$ levels would remain under $4 \%$ during the life of the unit (figure 12).

Table 4 shows that 15 of 42 apparatus tested on the BMS experienced $\mathrm{CO}_{2}$ breakthrough before expenditure of the $\mathrm{O}_{2}$ supply; 11 of these occurred before $60 \mathrm{~min}$. None of the new units experienced premature breakthrough. The response to high inhaled levels of $\mathrm{CO}_{2}$ will be increased ventilation rates in most users. Increased ventilation rates will result in higher breathing pressures experienced by the user. Breathing resistance in the SR-100 increases rapidly toward end-of-life even in new apparatus, and elevated $\mathrm{CO}_{2}$ levels will only add to this.
Table 4.-CSE SR-100 $\mathrm{CO}_{2}$ breakthrough times, minutes

\begin{tabular}{cccc}
\hline $\begin{array}{c}\text { Type of unit and } \\
\text { test method }\end{array}$ & $\begin{array}{c}\mathrm{CO}_{2} \\
\text { breakthrough } \\
\text { time }\end{array}$ & $\begin{array}{c}\text { Test } \\
\text { duration }\end{array}$ & $\begin{array}{c}\text { Maximum } \\
\mathrm{CO}_{2}\end{array}$ \\
\hline Deployed: BMS $\ldots \ldots$ & 59 & 60 & 4.4 \\
& 56 & 58 & 5.0 \\
& 58 & 62 & 6.0 \\
& 15 & 65 & 12.2 \\
& 57 & 63 & 10.2 \\
& 55 & 63 & 6.2 \\
& 60 & 61 & 7.4 \\
& 58 & 66 & 4.0 \\
& 64 & 65 & 9.6 \\
& 57 & 63 & 4.5 \\
& 66 & 66 & 4.5 \\
& 49 & 60 & 8.0 \\
& 58 & 64 & 7.2 \\
Deployed: Human & 66 & 68 & 4.7 \\
subject on treadmill & 50 & 52 & 4.3 \\
& 49 & 49 & 4.6 \\
\hline
\end{tabular}

$\mathrm{CO}_{2}$ breakthrough for BMS - $4 \%$ average inhaled; for treadmill - $4 \%$ minimum inhaled.

The Wilcoxon rank-sum test also shows that new units had statistically significantly higher wet- and dry-bulb temperatures than deployed units. This may be a reflection of more complete reaction of the bed chemicals in new units.

Three units had no or insufficient starter oxygen, requiring a manual start before beginning or shortly after beginning the test. There were five instances of either the top, bottom, or both lids being particularly hard to remove. These occurrences were all in apparatus manufactured prior to March 1992; a part change in late 1994 was designed to prevent this problem. Two of the four units used in human-subject tests caused coughing upon donning. One of the test subjects reported burning at the back of his throat in addition to coughing. As a result, 10 breaths were exhaled into the unit to wet down the offending dust (presumably corn starch, which is used by the manufacturer to keep saliva from reaching the chemical bed), after which testing continued normally. Two BMS tests were terminated due to breathing pressures that exceeded the range of the pressure transducer $\left(700 \mathrm{~mm} \mathrm{H}_{2} \mathrm{O}\right)$. All of the others were terminated with flat bags or high $\mathrm{CO}_{2}$ (table 4).

\section{DRAEGER OXY K-PLUS}

Two deployed units passed the leak-tightness test and seven failed; two new units passed the test and one failed.

The Wilcoxon rank-sum tests [M=3; N=9] for the Draeger show that new units could not be distinguished from deployed units in any measured parameter.

No deployed or new units experienced $\mathrm{CO}_{2}$ breakthrough.

No problems were evident in the 10 apparatus from the targeted sample. However, a mine using both CSE SR-100s and 

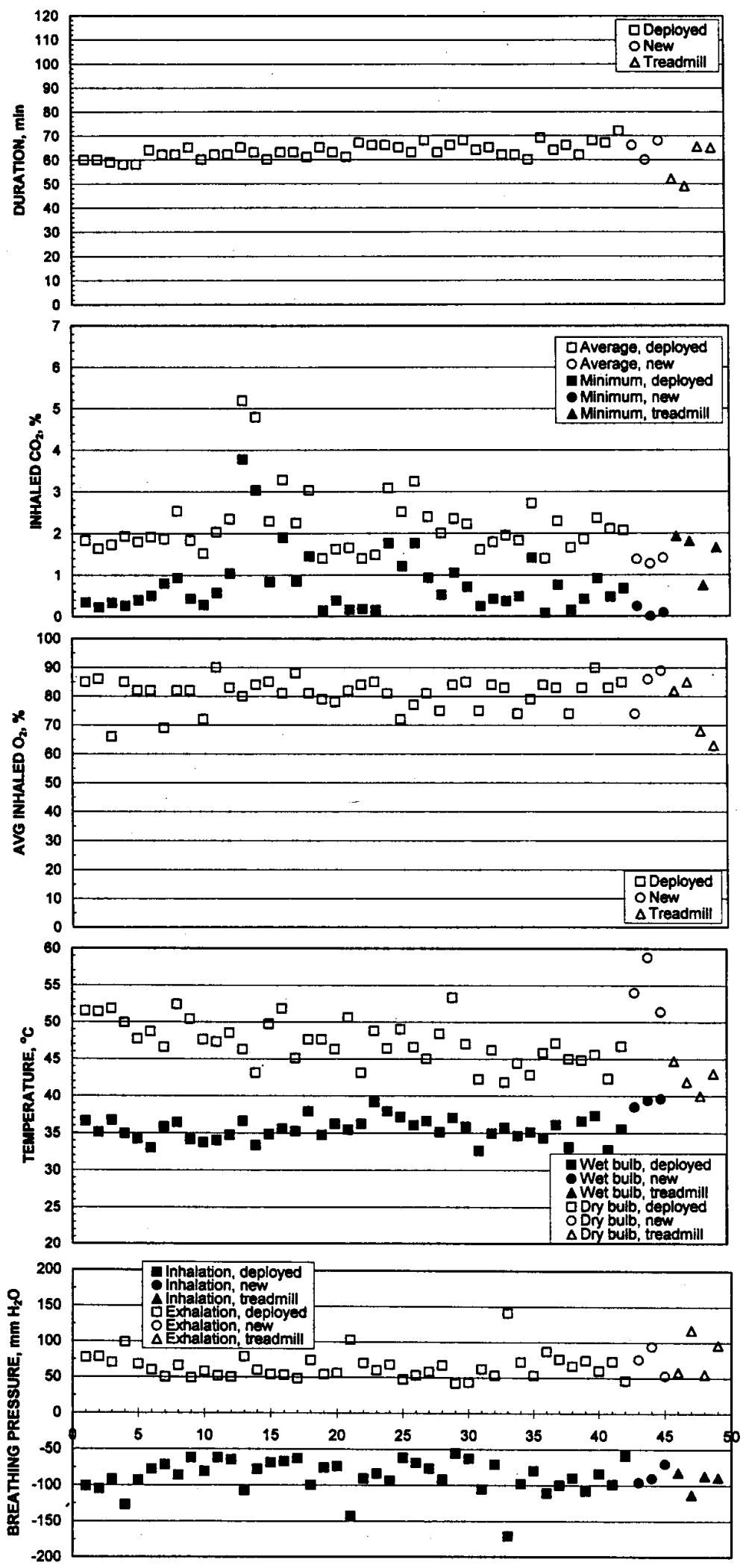

INDIMDUAL UNITS

Figure 7.-CSE SR-100 test results. 

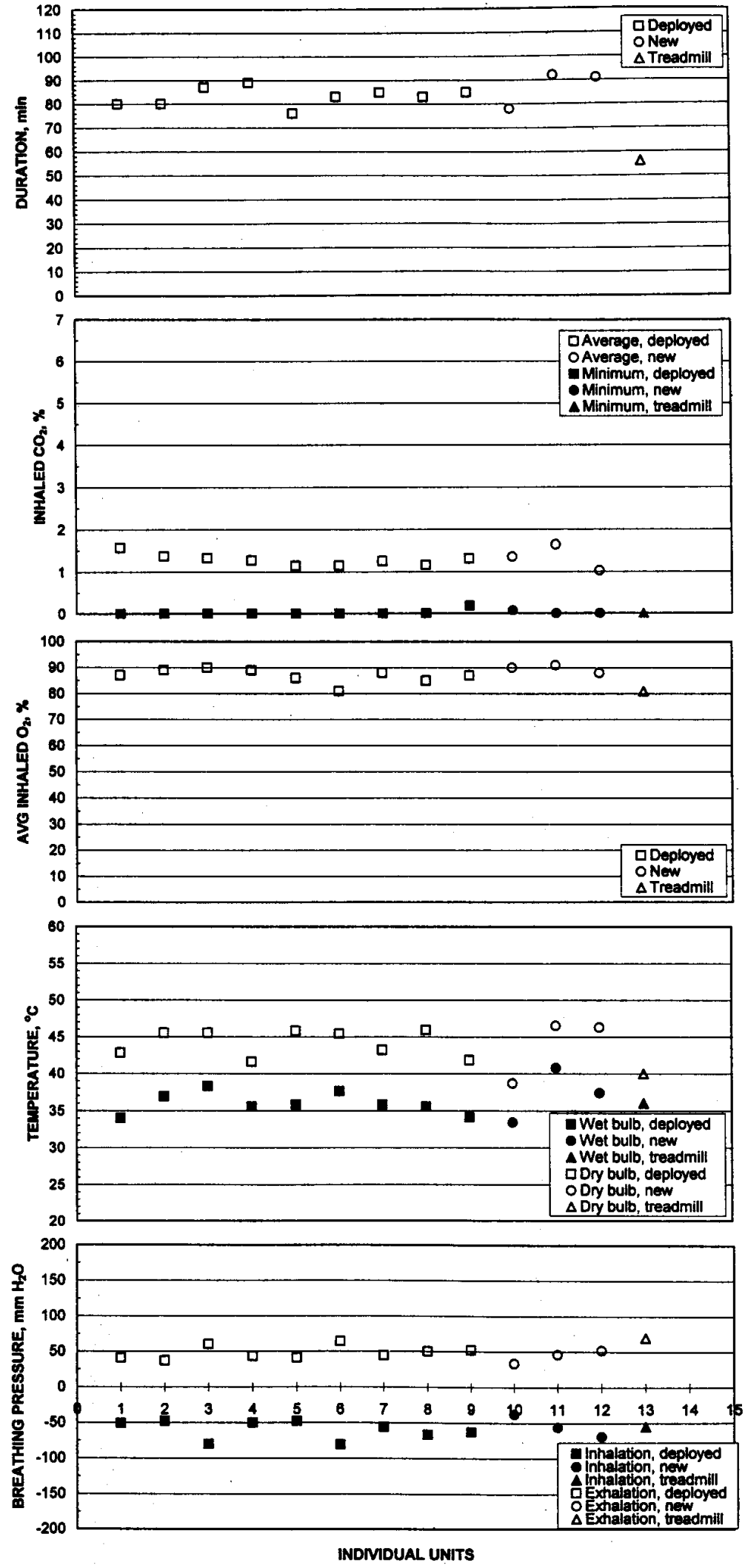

Figure 8.-Draeger OXY K-Plus test results. 

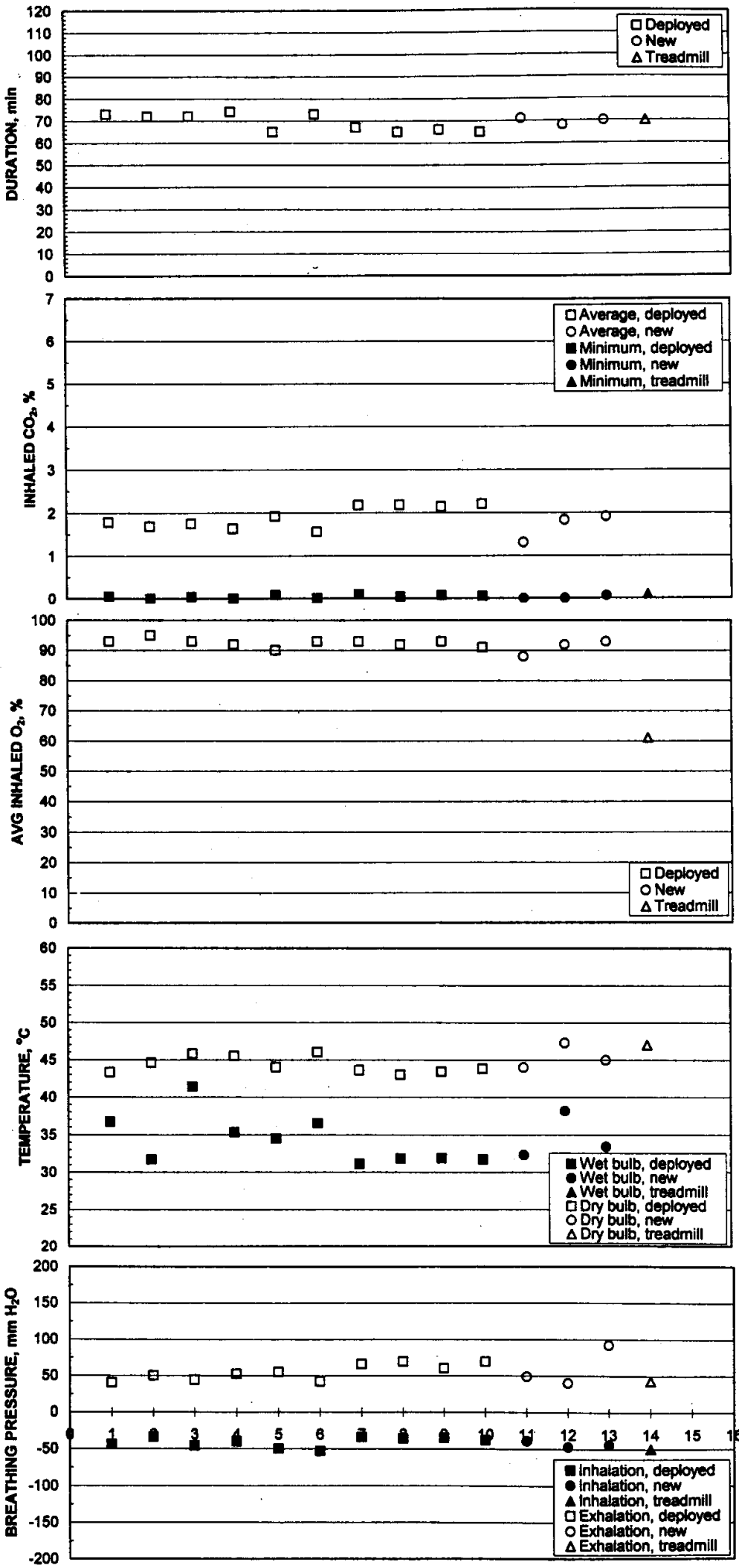

INDIMDUAL UNITS

Figure 9.-MSA Life-Saver 60 test results. 


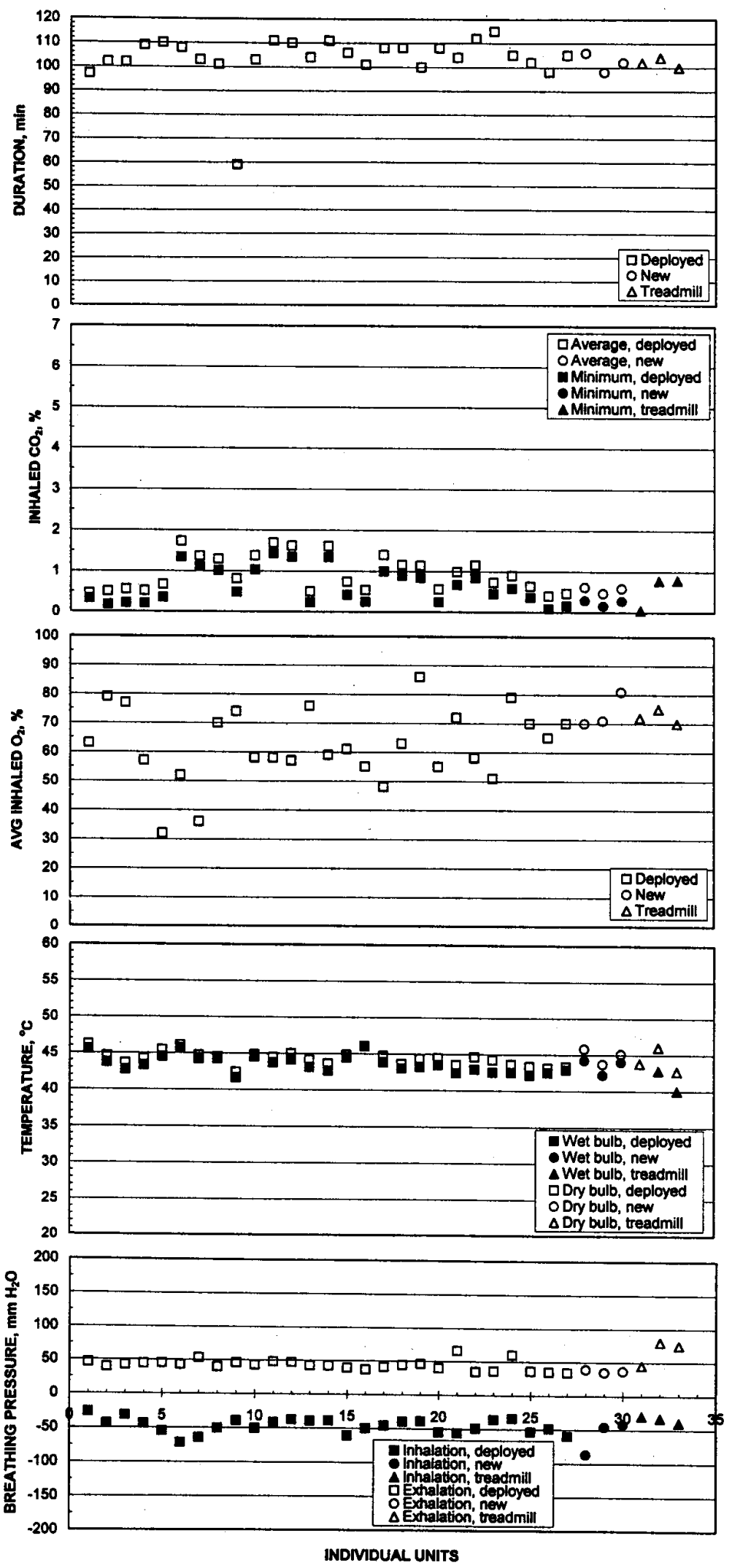

Figure 10.-Ocenco EBA 6.5 test results. 

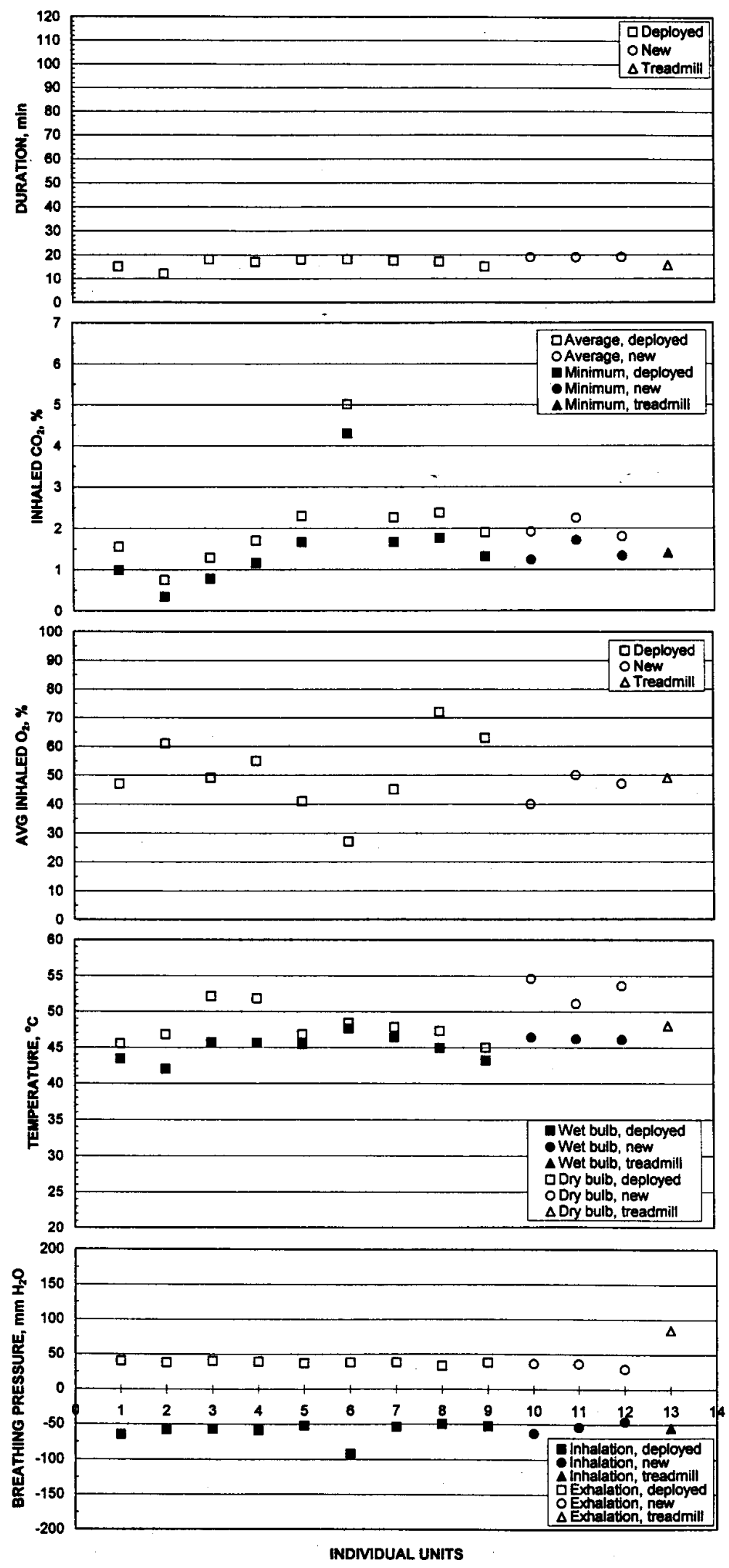

Figure 11.-Ocenco M-20 test results. 


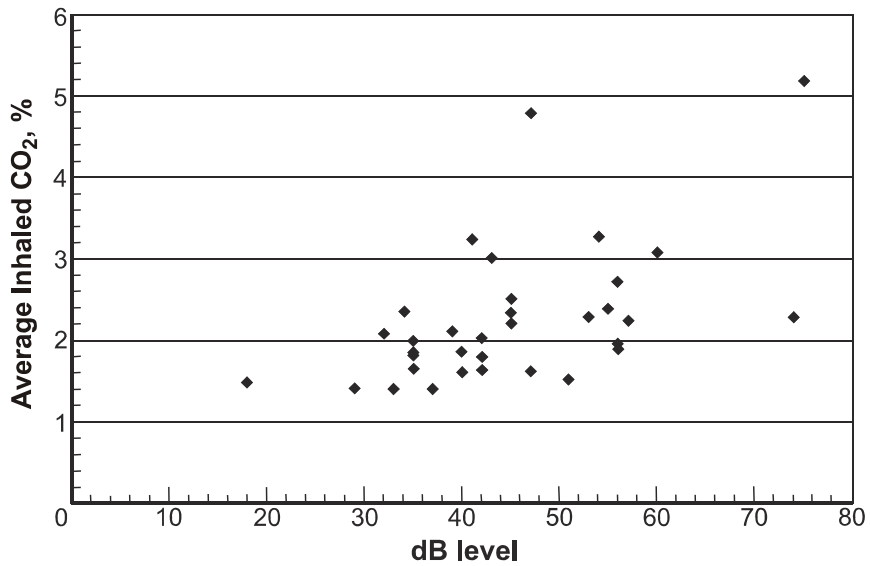

Figure 12.-CSE SR-100 DB level versus $\mathrm{CO}_{2}$ level.

Draeger OXY K-Pluses decided to try the CSE shake test on its Draeger units and found that some of them rattled. The mine expressed concern to MSHA, which asked us to inspect five of these apparatus. We found that some of the apparatus had leaked $\mathrm{KO}_{2}$ into the breathing circuit on both sides of the canister-inside both the breathing bag and breathing hose. Three of these units were missing the metal plates on which are written the serial number and manufacturing date, and which contain the belt loops. These apparatus, therefore, did not pass inspection. Some of the units that had $\mathrm{KO}_{2}$ leakage, however, did pass inspection and, as a result, an investigation by NIOSH, MSHA, and Draeger was undertaken. Draeger has developed a shake test for the OXY K-Plus.

\section{MSA LIFE-SAVER 60}

Nine of the eleven deployed units passed the leak test; all three of the new units passed.

The Wilcoxon rank-sum tests $[M=3, N=10]$ show that new units did not perform differently from deployed units in any performance measure.

No deployed or new units experienced $\mathrm{CO}_{2}$ breakthrough.

The low oxygen level during the treadmill test (figure 9) was caused by a poorly fitting nose clip on the human test subject.

One unit had a small slit in the breathing bag. An inspection by NIOSH, MSHA, and MSA of approximately 100 units produced over the same time period revealed no further similar damage. It was determined that the isolated case was a manufacturing defect. Although the unit behaved normally in the BMS test, it must be assumed that any breach in the breathing circuit is a serious defect that can admit toxic gases into the breathing circuit. A hole in the breathing bag, however, is likely to admit a smaller quantity of ambient air into the breathing circuit than a hole in the inhalation hose, for example, since the pressure in the bag is usually very close to ambient pressure, whereas the inhalation hose will see greater negative pressures.

One deployed unit had a large dent on its lid, which required it to be removed from service. It was tested anyway, however, and behaved normally in the BMS test. All such units that escape detection by the mine operator, MSHA, and our own inspections are tested to determine if they would have performed acceptably. If they had not been collected as part of our study, they could have been used in an emergency situation.

\section{OCENCO EBA 6.5}

None of the 30 deployed apparatus tested for breathing circuit tightness passed the leak test; 1 of the 3 new apparatus passed. Some units passed the test when their relief valves were capped, however, which implies backflow leakage through the valves.

The Wilcoxon rank-sum tests [M=4; $=27]$ show that, in all performance measures, new units could not be distinguished from deployed units.

No deployed or new units experienced $\mathrm{CO}_{2}$ breakthrough.

The large range of average inhaled $\mathrm{O}_{2}$ level test averages is due to the difference in the apparatus $\mathrm{O}_{2}$ regulator flow rates, which ranged in this phase from 1.53 to $1.93 \mathrm{~L} / \mathrm{min}$ ATPD. The $\mathrm{O}_{2}$ concentration in a breathing circuit will rise if the $\mathrm{O}_{2}$ supply rate is higher than the $\mathrm{O}_{2}$ consumption rate.

In this phase, we found two units in which the orange cylinder bands had shifted, five units with cracks in their cases, and one unit with a blown-out case gasket. Any of these signs require the apparatus to be removed from service. In one unit with a case crack, the $\mathrm{O}_{2}$ flow was so high that the cylinder emptied in $59 \mathrm{~min}$. In this instance, a shorter-than-normal duration would have been the only consequence. Another unit with case cracks had a demand valve which, when activated, stuck open. Turning off the cylinder valve closed the demand valve; this was done and the test was completed normally. Had this not been done, a severely curtailed duration would have resulted in this unit as well. The other units with disqualifying damage behaved normally. What remains of concern is the fact that damage requiring these units to be removed from service is very difficult to detect when the apparatus are dirty. The apparatus are cleaned after they are procured from the participating mines and only then does the damage reveal itself. The caution we issue is this: an apparatus caked with dirt cannot be properly inspected; dirt hides damage that may be critical.

\section{OCENCO M-20}

Of the nine deployed units tested for leak-tightness, two passed; of the three new units, two passed.

Four deployed and all three of the new apparatus experienced average inhaled $\mathrm{CO}_{2}$ levels of $4 \%$ before exhaustion of the $\mathrm{O}_{2}$ supply (table 5). In all but one instance, however, the depletion of the $\mathrm{O}_{2}$ supply was only $1 \mathrm{~min}$ or less away. One apparatus experienced $\mathrm{CO}_{2}$ breakthrough at minute 5 with a final duration of $18 \mathrm{~min}$, at which time the average inhaled $\mathrm{CO}_{2}$ had reached $7.5 \%$. This unit also had a noticeable quantity of lithium hydroxide $(\mathrm{LiOH})$ in the breathing bag and a lower-than-normal $\mathrm{O}_{2}$ flow rate, as evidenced by continuous demand valve use. The continuous use of the demand valve would have been of no 
import to a user since a high work rate would also require continuous use of the demand valve. The $\mathrm{LiOH}$ dust in the breathing bag also would not have affected a user since none was found in the mouthpiece, but the higher $\mathrm{CO}_{2}$ values might have caused a higher ventilation rate in a user. It is likely that the LiOH in the breathing bag is evidence of chemical bed deterioration caused by physical impact from deployment (belt wear), which resulted in the higher $\mathrm{CO}_{2}$ values. Environmental simulation tests [Kyriazi 1996] showed similar results of LiOH escaping the chemical bed. NIOSH, MSHA, and Ocenco are currently investigating the problem.

Table 5.-Ocenco M-20 CO $\mathrm{CO}_{2}$ breakthrough times, minutes

\begin{tabular}{cccc}
\hline $\begin{array}{c}\text { Type of unit and } \\
\text { test method }\end{array}$ & $\begin{array}{c}\mathrm{CO}_{2} \text { break- } \\
\text { through time }\end{array}$ & $\begin{array}{c}\text { Test } \\
\text { duration }\end{array}$ & $\begin{array}{c}\text { Maximum } \\
\mathrm{CO}_{2}\end{array}$ \\
\hline Deployed: BMS . . . & 17 & 18 & 4.4 \\
& 5 & 18 & 7.5 \\
& 17 & 17.5 & 4.5 \\
New: BMS . . . . . . & 16 & 17 & 4.8 \\
& 19 & 19 & 4.1 \\
& 18 & 19 & 5.0 \\
\hline
\end{tabular}

$\mathrm{CO}_{2}$ breakthrough for BMS - $4 \%$ average inhaled; for treadmill $4 \%$ minimum inhaled.

The Wilcoxon rank-sum test $[\mathrm{M}=3 ; \mathrm{N}=9]$ revealed that durations for deployed units were statistically significantly lower than those for new units. This could be caused by gas leakage from the cylinders or higher regulator flow rates in the deployed units. All of the apparatus had cylinder pressures in the acceptable (green) range. Since checking the cylinder gauge is one of the inspection criteria, apparatus having significantly low pressures would presumably be removed from service and would not present a serious problem. Also, since the durations of deployed units were only 2 min lower than those of new units (17 versus $19 \mathrm{~min}$ ), this finding is not viewed with concern at present, but will be monitored for greater effects in future phases of this study.

The Wilcoxon rank-sum test also showed that dry-bulb temperatures for new units may be statistically significantly higher than those for deployed units and that exhalation pressures for new units may be statistically significantly lower than those for deployed units. Dry-bulb temperatures of new units that are higher than those for deployed units may indicate lower reactivity of the chemical bed in deployed units. However, since $\mathrm{CO}_{2}$ levels were the same for new and deployed units, this finding is of no concern. Higher exhalation pressures for deployed units might indicate powdering of the chemical beds. However, since the pressures for new and deployed units were found to be so similar (see figure 11), this finding can be ignored and is attributable to the rank-sum test's inability to distinguish between large and small differences in values.

Several M-20s had dirt migration into the cases, which indicates breaches in the case seals. One unit was missing its top bumper pad, which indicates rough usage. However, all of these apparatus performed normally.

\section{CONCLUSIONS}

The results of this study suggest that the large majority of SCSRs that pass their inspection criteria can be relied upon to provide a safe level of life support capability for mine escape purposes. However, the mining environment seems to have caused some performance degradation in the CSE SR-100, Draeger OXY K-Plus, and Ocenco M-20. CSE has added a shake test to its inspection criteria in order to detect damage to the SR-100 chemical bed, which results in early $\mathrm{CO}_{2}$ breakthrough. Several Draeger OXY K-Pluses were found with significant quantities of chemical in both the mouthpiece side of the breathing circuit and the breathing bag. As a consequence, Draeger developed a shake test to detect such damage. One Ocenco M-20 was found with chemical in the breathing bag; this unit also experienced early $\mathrm{CO}_{2}$ breakthrough and is presently under investigation. The MSA Life-Saver 60 was only
c
e

introduced into the mines and has not been observed to suffer any hidden damage. The Ocenco EBA 6.5 is not belt-worn; it is thus spared from the greater degree of impact brought by belt wear. The greatest problem we have seen with it over the years is that, because the outer case is so tough, a severe impact may result in only a small crack that is not easily visible, especially if concealed by dirt. Such severe impact, however, may result in critical internal damage, which can compromise successful use of the device. Examples from past phases are damaged demand valves with high flow rates resulting in low durations; demand valves with cracked housing permitting in-leakage of ambient air; and damaged canisters resulting in $\mathrm{LiOH}$ spilling into the breathing circuit. Because of the importance of easy visual inspection, it is recommended that deployed apparatus of all types be cleaned of mine dirt for their regular inspections. 


\section{ACKNOWLEDGMENTS}

Without the cooperation of the coal mines and MSHA field offices, this study would not be possible. The following coal mines and MSHA field offices participated in the seventh phase of this study.

\begin{tabular}{|c|c|c|}
\hline \multicolumn{2}{|c|}{ Cooperating mine or MSHA office } & \multirow{2}{*}{ Location } \\
\hline Mining company & Mine name & \\
\hline \multicolumn{3}{|l|}{ MSHA District 2: } \\
\hline MSHA inspectors & - & Ruff Creek, PA. \\
\hline Cyprus Emerald Resources Corp. . . . . . & Emerald Mine No. 1 & Waynesburg, PA. \\
\hline \multicolumn{3}{|l|}{ MSHA District 3: } \\
\hline Anker West Virginia Mining Co. . . . & Stony River Mine & Mount Storm, WV. \\
\hline Wayne Processing, Inc. . . . . . . . . . . . & Sentinel Mine & Philippi, WV. \\
\hline Coastal Coal/West Virginia LLC & Whitetail Mine & Kingwood, WV. \\
\hline Dana Mining Co., Inc. . . . . . . . . & Prime No. 1 Mine & Morgantown, WV. \\
\hline BJM Coal Co. . . & Mine 9A. & Summersville, WV. \\
\hline \multicolumn{3}{|l|}{ MSHA District 4: } \\
\hline MSHA inspectors . . & - & Mount Hope, WV. \\
\hline Speed Mining, Inc. . . & Still Run No. 4 Mine & Beckley, WV. \\
\hline Quality Energy, Inc. . & Mine No. 1 & Princeton, WV. \\
\hline Ambush Mining Co., Inc. & Caretta No. 1 Mine. & Caretta, WV. \\
\hline \multicolumn{3}{|l|}{ MSHA District 5: } \\
\hline Falcon Coal Co. & Mine No. 4 & Grundy, VA. \\
\hline MSHA District 6: & & \\
\hline Husky Coal Co., Inc. & Mine No. 7 & Ashcamp, KY. \\
\hline \multicolumn{3}{|l|}{ MSHA District 7: } \\
\hline Leeco, Inc. . . . & Mine No. 68 & London, KY. \\
\hline \multicolumn{3}{|l|}{ MSHA District 8: } \\
\hline Black Beauty Underground, Inc. & Air Quality No. 1 Mine & Evansville, IN. \\
\hline Old Ben Coal Co. . . . . & Zeigler No. 11 Mine & Courterville, IL. \\
\hline Peabody Coal Co. . . . . & Marissa Mine $\ldots \ldots \ldots \ldots$ & Marissa, IL. \\
\hline White County Coal Corp. & Pattiki Mine $\ldots \ldots \ldots \ldots$ & Henderson, KY. \\
\hline Catlin Coal Co., Inc. . . . . . . . . . . & Riola Mine $\ldots \ldots \ldots \ldots$. . . & Catlin, IL. \\
\hline
\end{tabular}

\section{REFERENCES}

Hodgson, JL [1993]. Physiological costs and consequences of mine escape and rescue. University Park, PA: The Pennsylvania State University. U.S. Bureau of Mines contract Nos. J0145038 and J0345327.

Kyriazi N [1996]. Performance comparison of second-generation oxygen self-rescuers. Pittsburgh, PA: U.S. Department of Energy, RI 9621.

Kyriazi N, Shubilla JP [1992]. Self-contained self-rescuer field evaluation: results from 1982-90. Pittsburgh, PA: U.S. Department of the Interior, Bureau of Mines, RI 9401.

Kyriazi N, Shubilla JP [1994]. Self-contained self-rescuer field evaluation: fourth-phase results. Pittsburgh, PA: U.S. Department of the Interior, Bureau of Mines, RI 9499.
Kyriazi N, Shubilla JP [1996]. Self-contained self-rescuer field evaluation: fifth-phase results. Pittsburgh, PA: U.S. Department of Energy, RI 9635.

Kyriazi N, Shubilla JP [2000]. Self-contained self-rescuer field evaluation: sixth-phase results. Pittsburgh, PA: U.S. Department of Health and Human Services, Public Health Service, Centers for Disease Control and Prevention, National Institute for Occupational Safety and Health, DHHS (NIOSH) Publication No. 2000-128, IC 9451.

Kyriazi N, Kovac JG, Shubilla JP, Duerr WH, Kravitz J [1986]. Selfcontained self-rescuer field evaluation: first-year results of 5-year study. Pittsburgh, PA: U.S. Department of the Interior, Bureau of Mines, RI 9051. 


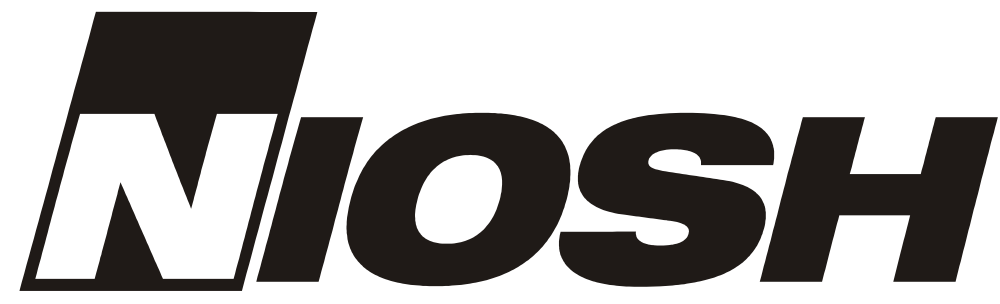

Delivering on the Nation's Promise: Safety and health at work for all people Through research and prevention

For information about occupational safety and health topics contact NIOSH at:

1-800-35-NIOSH (1-800-356-4674)

Fax: 513-533-8573

E-mail: pubstaft@cdc.gov

www.cdc.gov/niosh

DHHS (NIOSH) Publication No. 2002-127 